\title{
International sport federations' commercialisation: a qualitative comparative analysis
}

Josephine Clausen ${ }^{1}$, Emmanuel Bayle ${ }^{1}$, David Giauque ${ }^{2}$, Kaisa Ruoranen ${ }^{3}$, Grazia Lang ${ }^{3}$, Torsten Schlesinger ${ }^{4}$, Christoffer Klenk $^{3} \&$ Siegfried Nagel ${ }^{3}$

${ }^{1}$ Institute of Sports Studies, Université de Lausanne, Switzerland

${ }^{2}$ Institute of Political, Historical and International Studies, Université de Lausanne, Switzerland

${ }^{3}$ Institute of Sport Science, Universität Bern, Switzerland

${ }^{4}$ Institute of Human Movement Science and Health, Technische Universität Chemnitz, Germany

\begin{abstract}
Research question: This study examines the conditions and configurations that particularly influence International Federations' (IFs) commercialisation.

Research method: Crisp-set qualitative comparative analysis (csQCA) is used to determine the conditions that are related to an IFs' commercialisation. Sixteen interviews were conducted in six Olympic IFs and one international sport umbrella organisation.

Results and Findings: The findings reveal a variety of high and low commercialisation configurations. Specialisation is a key condition in both high and low commercialisation, and social media engagement is central in high commercialisation. Strategic planning and low accountability have low degrees of overlap with high commercialisation outcomes. With 13 out of 22 IFs achieving high levels of commercialisation, the findings demonstrate that IFs are increasingly developing business-like behaviours.
\end{abstract}

Implications: The findings highlight the importance of specialisation and social media engagement to achieve high commercialisation. However, when IF's assume a monetisation agenda, there are associated risks such as stakeholder legitimacy, mission drift, goal vagueness and adherence to good governance principles.

Keywords: Olympic international federations, commercialisation, set-theoretic method, mission drift

\section{Introduction}

Contemporary International Sport Federations (IFs) are not only custodians of their sport's policies, rules and regulations, but they also manage business activities such as major international sport events (Clausen \& Bayle, 2017) and commercial contracts (Cornelissen, 2010). The changing nature of sport can be seen in national sport federations (NFs) through to sport clubs (Girginov \& Sandanski, 2008; Skinner, Stewart, \& Edwards, 1999). Research on IF's has examined athletes' involvement in policy-making (Thibault, Kihl, \& Babiak, 2010), stakeholder engagement in major events (Parent \& Séguin, 2007) and, more recently, social media communication (Belot, Winand, \& Kolyperas, 2016). Corruption within the International Olympic Committee (IOC) (Chappelet, 2011; MacAloon, 2011), doping in cycling (Wagner, 2010), and governance issues within wealthy IFs such as the International 
football federation (FIFA) (Bayle \& Rayner, 2016; Pielke, 2013) create global headlines and have dominated the IF research agenda.

General trends in nonprofit organisations (NPOs) such as marketisation, commercialisation, and commodification of services and activities (Maier, Meyer, \& Steinbereithner, 2014) have been linked to a process of professionalisation in sport (Nagel, Schlesinger, Bayle, \& Giauque, 2015; O'Brien \& Slack, 2004) that is evidenced in rationalisation (e.g. rules, workflow) and the adoption of corporate management practices (e.g. strategic planning) to enhance organisational effectiveness and efficiency (Chantelat, 2001; Dowling, Edwards, \& Washington, 2014).

This study seeks to explore the commercialisation of IF's sporting events by analysing various factors of influence (conditions) and their underlying configurations (combination of conditions). The research question is: which conditions and configurations influence IFs' commercialisation? Through identifying, analysing and discussing conditions and configurations, an explanatory model for IFs' pathways towards high commercialisation is proposed.

As commercialisation in international sport has focused on cash rich organisations such as FIFA and the IOC, we are particularly interested to see if and how smaller IFs achieve commercialisation. In examining if commercialisation is a viable strategy to diversify revenue, we assess IFs' capacity to achieve self-sufficiency in times of increasing competition for scarce resources. The study draws on research on commercialisation in NPOs (Abeza, O'Reilly, \& Reid, 2013; Bryson, 1988) and sport organisations in particular (Bayle \& Robinson, 2007; Forster, 2006); internal documents (e.g. IF statutes and regulations) and interviews with IF employees.

\section{Commercialisation of Nonprofit Organisations}

The environment for NPOs has become increasingly competitive, complex and uncertain, thus entailing the need to manage resources more efficiently and effectively (Froelich, 1999; Maier et al., 2014; Young, 1998). NPOs' increasing market orientation can be seen as "an adaptive strategy for ensuring that organisations receive the necessary resources for accomplishing their mission and carrying out their activities" (Macedo \& Carlos Pinho, 2006, p. 538). Others fear that NPOs' increased blending of service-oriented and profit-oriented objectives may lead to goal and mission displacement (Dees \& Anderson, 2003; Toepler, 2004; Weisbrod, 1998). On one hand, there is a risk of mission displacement and loss of values; on the other hand is the prospect of self-sufficiency, reduced uncertainty and greater efficiency and 
effectiveness in an increasingly complex, challenging environment (Toepler, 2004) with commercialisation as an opportunity for obtaining additional resources to be used for good purposes (Clotfelter \& Ehrlich, 2001).

While commercial ventures are not new in the NPO-sector, the dramatic acceleration in recent decades is striking and sits within a context of political, economic and technological issues. Two major aspects contribute to this evolution: declining private and public grants and subsidies, individual and corporate donations (Smith, 2016), the traditional cornerstones of NPOs' financial model (Froelich, 1999); and, as a result of the first, growing competition between nonprofits for scarce funding (Smith, 2010) and with for-profits that offer similar services (Coghlan \& Noakes, 2012). In response, over the past 20+ years, NPOs have increasingly sought to diversify their revenue (Carroll \& Stater, 2009; Chang \& Tuckman, 1994). In sport management literature, several studies conclude that decreasing private donations and public funding trigger national sport organisations' commercialisation (Berrett \& Slack, 2001 ; Houlihan, 1997; Nagel et al., 2015).

\section{Commercialisation of nonprofit sport organisations}

In sync with the NPO literature, studies of national sport organisations note that commercialisation is related to a sector-wide resource shortage in (government) funding (Nagel et al., 2015; O'Brien \& Slack, 2004) and strategies of resource diversification employed in response to financial uncertainty (Wicker, Feiler, \& Breuer, 2013). Considering the consequences of both financial uncertainty and new managerial approaches, Robinson (2003) described sport as "a business that competes for scarce consumer resources, requiring a business approach to its management, utilising professional management techniques" ( $p$. 308). Robinson distinguishes four factors that have given rise to the commercialisation of sport: a trend towards sport spectating, changing technologies, increasing competition and professionalisation of sport management.

Amis, Slack and Hinings' (2004) research provided evidence that sport organisations are compelled to professionalise and commercialise in order to adapt to an increasingly complex and competitive environment. Professionalisation has led to increases in the level of specialisation and the hiring of paid staff (Kikulis, 2000; Thibault, Slack, \& Hinings, 1991). It is assumed that sport organisations with more paid staff, greater functional division of labour and formalised procedures can commercialise more easily as the expert knowledge of paid staff allows them to adapt more readily to environmental changes. Analysing the performance of French national sport organisations, Bayle and Robinson (2007) relate the staff headcount 
to four phases of professionalisation: first restructuring (5-10 staff), functional specialisation (15-40 staff), coordination (>40 staff) and professionalisation of the network (>100 staff).

While NPO's and national/state sport organisations have had to respond to environmental financial uncertainty, and notably a decline of public contributions, IFs have not experienced a significant income gap. On the contrary, the initial member contribution based funding model was augmented by commercial activities. The concept of IFs' commercialisation can be linked to their professionalisation and internationalisation (Forster \& Pope, 2004), while revenues through commercial activities are mainly related to sport events, including broadcasting and sponsorship rights (Li, MacIntosh, \& Bravo, 2012; Slack, 2004). The sport event has become an exchange currency that offers businesses "increased awareness, image enhancement, product trial or sales opportunities (Crompton, 2004, p. 268).

Bayle (2015) describes IFs' events as "the heart of their economic model" (p. 109). Revenue from hosting fees, broadcasting and sponsorship rights allow IFs to finance their operational activities (e.g. administration), build up reserves and increase their selfsufficiency. While the initial arguments behind commercialising IFs' events were to ensure a federation's economic stability and to increase its development activities, Krieger (2016) claims that, in the case of the International Association of Athletics Federation (IAAF), as early as 1977 "the technical development initiatives served as a tool to justify the commercialisation of the IAAF and athletic sport" (p. 1345). Forty years later, the development argument is still being used to justify commercialisation, especially by rich IFs. Though FIFA emphasises that it aims to "share the success of the FIFA World Cup with our member associations" (FIFA, 2016), IFs' commercialisation has been linked to excessive and negative effects such as corruption, fraud and bribery (Geeraert, 2015; Pielke, 2013). The lack of accountability mechanisms is particularly related to commercially successful sport organisations (Forster, 2006; Pielke, 2013) such as the IOC (Tomlinson, 2005) and FIFA (Cornelissen, 2010).

Based on previous research, we classify the commercialisation of IFs' sporting events as an adaptive strategy (Maier et al., 2014; Toepler, 2004; Tuckman, 1998) that both pursues the goal of mission accomplishment in an increasingly competitive environment (Macedo \& Carlos Pinho, 2006), and seeks to capitalise on the constantly growing commodification of sport worldwide (Hargreaves, 2002; Slack, 2014). Our main goal is to determine how IFs commercialise and which conditions impact their commercialisation. Moreover, we seek to empirically uncover configurations (i.e. combinations of conditions) that favour high levels of 
commercialisation by using multiple sources to establish a list of conditions that are likely to influence IFs' levels of commercialisation. Our approach is informed by literature on commercialisation in the NPO sector (e.g. strategic planning) and in nonprofit sport organisations in particular (e.g. professionalisation, broadcasting, social media), as well as data sources described below.

\section{The method and technique of qualitative comparative analysis (QCA)}

QCA is particularly deployed in sociology and political science (Thiem \& Dusa, 2013). Management scholars used QCA to determine the performance of various organisational aspects such as strategy (Greckhamer, Misangyi, Elms, \& Lacey, 2008), high-tech considerations (Schneider, Schulze-Bentrop, \& Paunescu, 2010) and innovation (Ganter \& Hecker, 2014). Winand (2011, 2013, 2013) used QCA in analysing the performance of Belgian NFs, and Pinson (2017) in heritage sporting events. Dichotomous crisp-set QCA, as we use in this study, is particularly suitable for the analysis of causal complexity in small Nsamples, that is, for less than 30-40 cases (Rihoux, 2006). Our study includes 35 cases.

QCA is both a comparative case-oriented research approach and a technique based on set theory and Boolean algebra (Marx, Rihoux, \& Ragin, 2014; Ragin, 1987). As a research approach, it integrates "the best features of the case-oriented approach with the best features of the variable-oriented approach" (Ragin, 1987). Instead of being limited to a small number of hermeneutic in-depth case studies as in the traditional case-study approach, QCA allows researchers to explore and summarise the data of several cases and test hypotheses (BergSchlosser, De Meur, Rihoux, \& Ragin, 2008; Ragin \& Rihoux, 2004). The main strength of QCA as a research technique is that it enables the assessment of complex combinations of key factors (independent variables, called conditions) that are causally relevant to a specific phenomenon (dependent variable, called outcome). Focusing on causal configurations and context rather than on isolated aspects, the method assumes that organisations demonstrate multiple conjunctures of independent variables that may still lead to the same outcome (equifinality). Based on the idea that a complex phenomenon cannot be fully understood by examining isolated causal conditions but calls instead for a systemic and holistic approach (Fiss, 2007), QCA allows for causal complexity. Due to the context-specific notion of causality and the use of relatively small samples, QCA findings cannot be statistically generalised.

To assess the influence of several conditions on the phenomenon of IFs' commercialisation, we used the technique of crisp-set QCA (csQCA). csQCA translates base 
variables (called raw data) into two possible truth-values: true (or present) or false (or absent), generally denoted as 1 and 0 . We used two software programmes to analyse conditions and configurations. Tosmana (Cronqvist, 2011) transforms the raw data into a dichotomous data table called truth table. The truth table may produce five types of outcome: configurations with the outcome value [1], configurations with the outcome value [0], contradictory configurations ("CC"), logical remainders ("R") and cases for which the outcome is unknown. Contradictory configurations are those that lead "to a [0] outcome in some observed cases, but to a [1] outcome for other observed cases", while logical remainders are "logically possible combinations of conditions that have not been observed among the empirical cases" (Rihoux \& Ragin, 2008).

The second software fs/QCA (Ragin \& Davey, 2009) enables us to further analyse the truth table and carry out a necessity analysis for conditions, which is similar to the idea of significance in statistical models (Legewie, 2013). A condition is deemed necessary if it must be present for a certain outcome to occur. Two empirical measures of fit should be reported here: consistency and coverage. Consistency assesses the degree of necessity of a causal condition for a specific outcome to occur. Ranging from 0 to 1 , a score of 1 indicates perfect consistency, a score of 0, no consistency (Ragin, 2006). Maggetti and Levi-Faur (2013) suggest a consistency score should be above 0.90 or 0.95 . However, they also advise against applying thresholds in a mechanical way, pointing out that hypothesis testing calls for higher consistency compared to exploratory analysis. While Ragin (2008) sets the cut-off point for consistency at 0.75 , Schneider and Wagemann (2010) note that "in the case of necessary conditions, the consistency value should be set much higher" (p. 10). Consistency should also be evaluated for the solution term(s), indicating the degree to which a solution term represents a subset of an outcome (Marx et al., 2014).

Looking at the second measure of fit, coverage determines the empirical relevance of consistency values (Ragin, 2006). Coverage values need to be large enough to exclude triviality. Legewie (2013) sets the lowest boundary for coverage at $>0.5$. For both consistency and coverage measures, choices are research specific and hence need to be substantiated with arguments (Schneider \& Wagemann, 2010).

We used Tosmana for so-called Boolean minimisation, an operation that produces parsimonious solutions (called minimal formula) of identified causal regularities. In the process of Boolean minimisation, causal conditions that are redundant for an outcome to occur are removed, hence transforming long, complex expressions into shorter ones. Let us take two cases that both lead to the same outcome and differ in only one causal condition: 
$\mathrm{A}^{*} \mathrm{~B} * \mathrm{C} \rightarrow \mathrm{D}$ and $\mathrm{A} * \mathrm{C} \rightarrow \mathrm{D}$. In this example, $\mathrm{B}$ can be removed, as it is irrelevant for the outcome. As perfect causal symmetry is unlikely to occur in social phenomena (Rihoux \& De Meur, 2009), the Boolean minimisation has to be carried out for both configurations leading to a [1] and a [0] outcome.

Before assessing conditions, researchers must first assess the outcome. In what follows, we describe how the commercialisation of Olympic IFs is measured, explain how conditions are selected and assessed and, finally, set forth how we collected data. The analysis of Olympic IFs for two reasons: firstly, for QCA studies it is advisable to compare "cases that share a sufficient number of features and that operate within sufficiently comparable contexts" (Rihoux, 2006); secondly, the IOC requires Olympic IFs to publish annual financial statements which are essential for our evaluation of their commercial revenues.

\section{Measurement of the commercialisation of Olympic IFs}

IFs' commercialisation is evaluated by analysing the contribution of event revenue (i.e. hosting fees, broadcasting and sponsorship rights) to the federation's overall income. Membership and licence fees are not considered as commercial revenues in this study. Fees are generally kept low to allow the membership base to grow rather than maximising profits through it. Although exceptions may exist, an increase in revenues from these fees is more likely to be related to the growing community of a sport than to commercialisation of the fees. We examined 2012-2015 financial statements (summer Olympic IFs), and 2010-2013 (winter Olympic IFs). These periods correspond to the last completed summer and winter Olympic cycles. Notably, this period afforded good data as the IOC Code of Ethics set out since 2010 that Olympic IFs should audit and disclose financial statements on an annual basis. The aim of this requirement is to increase pressure on IFs to use their Olympic revenue only for Olympic purposes.

Furthermore, and as most IFs do not divide Olympic revenue into four equal annual years, incomplete financial statements during an Olympic cycle could result in a biased picture of IFs' financial situation. In order to reduce data inconsistencies, we apply normalisation rules ${ }^{1}$ to IFs for which financial statements are not available for the entire Olympic cycle. If IFs organise their flagship events (e.g. World Championships) on an annual, biennial or quadrennial basis commercial revenue from events may be subject to cyclical fluctuations and a focus on one or two financial years is likely to produce an incomplete picture. 
As we are particularly interested in configurations that lead to high levels of commercialisation, defining and justifying a threshold for high commercialisation based on theoretical considerations is required. Studies that distinguish levels of commercialisation for NPOs are limited. Enjolras (2002) analysed Norwegian voluntary sport clubs to see whether commercialisation through competitions, renting of infrastructure facilities, ancillary activities and sponsors was $\geq 50 \%$. In the case of IFs, commercialisation mainly relates to sport event revenues (i.e. competitions and sponsors). Infrastructure facilities income and ancillary activities (e.g. lotteries, cafeteria) are irrelevant for Olympic IFs. Besides commercial revenues, all Olympic IFs receive revenue from the IOC and annual affiliation fees from members. Supported by the example of Enjolras, we set the threshold for high commercialisation at $\geq 50 \%$ income from commercial revenues.

\section{Defining and assessing conditions for commercialisation}

After having determined the outcome, we need to define and assess causal conditions of potential empirical and theoretical relevance to IFs' commercialisation. We should note that the periods of investigation for the outcome and the conditions are not fully congruent. While the outcome is historical (2010-2013 and 2012-2015), the conditions are based on recent data (2015-2017). Most IFs only publish their financial statements one to two years after the end of the fiscal year as these are approved by the IF's congress, which, in several cases, only meets every two years (e.g. FIH - International Hockey Federation, FIS - International Ski Federation). The levels of commercialisation we could calculate for the 22 IFs that publish financial statements represent averages. We selected a period where data were available for the maximum possible number of the 35 Olympic IFs, accessing information from the IFs' websites and in public documents.

We assumed that IFs' average level of commercialisation is representative of the period of analyses. Securing a large contract or losing an important sponsor cannot be fully captured due to the time lag. Nevertheless, we are confident that this limit does not undermine our research results.

Conditions were deduced from multiple sources such as scholarly articles (literature review), documents (e.g. IF statutes, IOC Evaluation Criteria, web articles), and interviews with representatives from an umbrella organisation in international sport (Association of Summer Olympic International Federations - ASOIF) and IFs. Nine conditions emerged (Table 1) and due to the objections we rejected certain conditions. 
[Table 1 about here]

The remaining four conditions emerged from the literature - strategic planning (Stone \& Brush, 1996), specialisation (Bayle \& Robinson, 2007), use of social media (Abeza et al., 2013; Belot et al., 2016) and low accountability (Chappelet, 2011; Forster, 2006) - and were reinforced through interviews and further readings of documents (e.g. IOC Evaluation Criteria, Olympic Agenda 2020, reports, web articles). Considering the lack of models capable of explaining NPOs' levels of commercialisation, these conditions suggest a starting point for future research rather than claiming to be exhaustive.

\section{Strategic planning (STRAT)}

Strategic planning is considered a tool to envision, implement and achieve future goals, and is designed to provide structured processes that facilitate important decisions and actions (Bryson, 1988). An effective strategy formulation depends on "the consistency across rhetoric (what people say), choices (what people decide and are willing to pay for) and actions (what people do)" (Bryson, 1988, p. 77). A key objective of NPOs' strategic plan is resource acquisition (Stone \& Brush, 1996). Business partners may have various motivations to tie up with an IF (e.g. visibility, image, culture). However, they all presumably seek return on investment. We therefore assume that IFs establish a clear strategic plan with which profitoriented stakeholders can identify and to which they want to affiliate. A strategic plan is considered here as a tool for IFs both to attract and maintain business partners and manage their expectations, but also to promote and develop the sport. We therefore investigate whether the IFs have a strategic plan in 2016 that covers a minimum of three years. If a strategic plan ends in 2016, we examine whether the IF has a subsequent plan for 2017 and a minimum of three subsequent years. As the threshold, we use the presence [1] or absence [0] of such a strategic plan.

\section{Specialisation (SPEC)}

IFs' specialisation is evaluated using Bayle and Robinson's (2007) classification of professionalisation: first restructuring (5-10 staff), functional specialisation (15-40 staff), coordination (>40 staff) and professionalisation of the network (>100 staff). Coordination is characterised by "an increase in the level of support staff, and the hiring of marketing experts and management and coordination staff' (p. 262). Using the coordination phase as a threshold 
allows us to differentiate IFs into high ( $\geq 40$ staff, [1]) and low (<40, [0]) specialisation based on headcounts from 2016. This condition is termed "specialisation" in reference to Bayle and Robinson's classification stage of "coordination". We assume that increased delegation of operational tasks to experts facilitates IFs' commercialisation.

\section{Social media engagement (SOCM)}

Capable of creating high levels of social interaction (Smith \& Stewart, 2010), sport organisations focus increasingly on relationship marketing (Abeza et al., 2013) to attract and retain fans, business partners, media and customers/consumers. Social media represent a costeffective relationship tool to engage sport fans and attract business partners (Abeza et al., 2013; Belot et al., 2016). IFs' social media engagement is evaluated on the basis of the report Sport on Social 2017 published by REDTORCH (2017), a data-driven communications agency. The report provides an analysis of Olympic IFs official account followers and the number of interactions each account (i.e. Facebook, Twitter, Instagram and YouTube) had from February 2016 to February 2017. We split IFs into those with a higher social media engagement ([1]) being ranked in the top 50\%, and those with a lower social media engagement ([0]) being ranked in the lower 50\%. The International Triathlon Union (ITU) was $18 / 35$ and could be classified either with the top $50 \%$ or the lower $50 \%$. As the ITU did not achieve a top ten position in any of the four social media channels, it is classified with the lower $50 \%$. Other thresholds such as a minimum of two top ten positions were also tested. However, these were rejected as they led to contradictory configurations.

\section{Low accountability (LACC)}

Five accountability dimensions were determined. Transparency, participation, evaluation and complaints and responses were based on the accountability definition of the One World Trust and its Global Accountability Framework (Chappelet, 2011). Transparency, is "reliable financial information" (Chappelet, 2011, p. 321), thus we use annual financial statements for at least the last three years of the respective Olympic cycle. Participation is defined as “stakeholders' participation in its [IOC's] decisions" (p. 322). Our proxy measure is whether athletes have a voting right in the decision-making body (i.e. board), and whether this right is anchored in the IF's statutes/constitution. The dimension of evaluation encompasses "official and public reports" (p. 325) and is measured by regularly published reports or detailed meeting documents. Finally, complaints and responses and the question of whether IFs have an ethics commission or equivalent body is referred to under "ethics commission" (p. 325). 
We added the dimension of presidential term limits in statutes/constitution as the IOC has encouraged IFs to introduce term limits to strengthen good governance and transparency.

We use a six-point scale with the categories being "very low" $0 / 5$ dimensions, "low" 1/5 dimensions, "rather low" for 2/5 dimensions, "rather high" for 3/5 dimensions, "high" for $4 / 5$ dimensions and "very high" for 5/5. A score of [1] signals the presence of low accountability (very low, low, rather low) and a score of [0] indicates the opposite (rather high, high, very high accountability). Detailed research findings are available from the corresponding author upon request

\section{Data collection}

Measuring IFs' level of commercialisation is exclusively based on financial statements and reports published by the 35 Olympic IFs (winter Olympic IFs: 2010-2013, summer Olympic IFs: 2012-2015). The selection and assessment of conditions is premised on scholarly articles, documents and interviews. Secondary literature includes IOC documents (e.g. IOC Evaluation Criteria, Olympic Agenda 2020), IFs' statutes and regulations (e.g. to determine IFs' accountability in terms of participation, complaints and term limits) and other public documents from IFs (e.g. minutes from board and congress meetings, annual reports, strategic plans), reports (e.g. Action for good governance in international sport organisations/Play the Game, Sports governance observer/Play the Game), websites (e.g. to determine number of staff) and web articles (e.g. from Inside the Games).

A total of 16 interviews were conducted with six IFs (i.e. FIFA, FIH, FIS, FISA, UCI, UWW) and one umbrella organisation (i.e. ASOIF). We used existing contacts to approach several IFs of varying size, all based in Switzerland. The interviews were essential in the selection of conditions; and provided examples of individuals' actual experiences and opinions. With the exception of FIFA, at least one interview was with a strategic level and an operational level employee. The women (4) and men (12) interviewed had served 3 to 35 years in their IF. Interviewees were anonymised and were conducted face-to-face (10), by phone (3) and by email (3), the latter participants were asked for additional and explanatory information where necessary. Face-to-face interviews lasted between 30 and 105 minutes, were audio-recorded, transcribed verbatim (13 in English, three in French) and anonymised (A1-F1). To increase trustworthiness, interviewees were asked to confirm the transcribed interview. The changes requested concerned informal language and sensitive information. 


\section{Findings}

Thirteen of the 35 Olympic IFs did not publish any financial statements for the period investigated (indicated as "no public financial statement" in Table 2), while 10 IFs published all financial statements for the respective period. IFs for which the outcome could not be measured due to lack of available financial statements are excluded from the analyses (cf. Table 2 for IF abbreviations). Among the 22 cases, 13 achieved high commercialisation (COMM), meaning commercial activities ( $\geq 50 \%$ ) outweigh revenues from the Olympic revenue and member affiliation fees and nine cases show lower levels of commercialisation. In one exceptional case (i.e. FIE), private donations represent the main source of income. The raw data table integrates the four conditions associated with the given outcome of high or low event commercialisation.

[Table 2 about here]

Using Boolean algorithms, the dichotomous data of csQCA and by transforming the raw data from the 22 IFs into dichotomous data, the truth table reveals five configurations resulting in high commercialisation ([1]), three resulting in low commercialisation ([0]) and two contradictory configurations ([C]). Contradictory configurations are quite frequent in csQCA, and require deeper immersion into the cases (Rihoux \& De Meur, 2009). By changing the threshold for specialisation to $\geq 30$ staff instead of $\geq 40$, the contradictions can be resolved. A possible explanation is that IFs mainly employ administrative staff with the goal of increasing organisational efficiency and efficacy, while NFs employ many coaches to further the nation's sporting success. Therefore, a smaller headcount in IFs can still be indicative of the phase of coordination. The adaptation of the initial threshold is supported as the new threshold, which affects four IFs (i.e. BWF, FIH, FINA, IIHF), does not entail new contradictory configurations. Based on these arguments and using the new threshold, the truth table is now void of contradictions (Table 3).

[Table 3 about here]

Binary conditions allow two possible answers, hence splitting "the logical space into two equal parts" (Rihoux \& Ragin, 2008): 1 or 0. The number of possible configurations for our study (4 conditions) is thus $16\left(2^{4}\right)$. The truth table above only indicates observed 
configurations $(n=11)$, excluding logical remainders $(n=5)$. At the extremes are two IFs (FISA, ISSF) with low commercialisation ([0]) and a [0] value in all four conditions, and one IF (WR) with high commercialisation ([1]) and a [1] value in all four conditions. The tilde ( ) signifies logical negation. As the necessity analysis demonstrates (Table 4), only $\sim$ SPEC can be considered as a necessary condition according to Maggetti (2013) and Legewie (2013): referring to cases that achieve low levels of commercialisation ( COMM), SPEC shows perfect consistency (1) and a coverage large enough to exclude triviality (0.75). Using Ragin's (2006, 2008) consistency threshold of 0.75, even though this is below the recommended 0.90 , one can argue that two other conditions are necessary to achieve high levels of commercialisation: SPEC with a consistency score of 0.77 , especially considering its coverage (1.00), and SOCM, likewise with a consistency score of 0.77 but lower coverage (0.83).

[Table 4 about here]

In this study, the Boolean minimisation for high commercialisation produces three terms that together build the descriptive formula. The minimisation formula for low commercialisation produces two terms (Table 5):

[Table 5 about here]

The first formula reads as follows: configurations of the present sample that demonstrate high specialisation, or high social media engagement in combination with either low accountability or a strategic planning, achieve high levels of commercialisation (COMM). The second formula reads: configurations of the present sample that demonstrate either low specialisation in combination with low social media engagement, or low specialisation in combination with high accountability and absence of a strategic planning, result in low levels of commercialisation ( COMM). With fs/QCA software we can further assess the raw and unique coverage of the solutions, as well as combined solution coverage and consistency. Raw coverage assesses the empirical relevance of cases that cover a given path (Marx et al., 2014), while unique coverage "indicates how much a path uniquely covers" (Thomann, 2015). Finally, solution coverage indicates how much (percentage) the configurations combined account for the membership in a given outcome (Fiss, 2011). Table 5 underlines the importance of SPEC (77\%) to achieve high levels of commercialisation. It 
also reveals that the combination of $\sim$ SPEC and $\sim$ SOCM accounts for $78 \%$ of membership in the low commercialisation outcome.

\section{Discussion}

Findings from 22 Olympic IFs provide a useful starting point in terms of pathways to high commercialisation. At least three observations can be made from the QCA analysis: firstly, high specialisation (SPEC) is a key condition for the outcome of high commercialisation; secondly, social media engagement (SOCM) correlates with high commercialisation; thirdly, strategic planning (46\%) and lack of accountability (31\%) show relatively minor overlaps with the outcome of high commercialisation.

Specialisation in national sport organisations has been related to increasing workloads and growing work requirements in terms of skills and complexity of tasks (Amis et al., 2004; Thibault et al., 1991). At the international level, the increasing demand for, and revenues from, major sporting events are evidenced by a progressive hiring of paid staff. The cases of ISU, IJF and ITTF show that high event commercialisation is not just related to the number of paid staff. ISU, IJF and ITTF still achieve high event commercialisation through high social media engagement in combination with either a strategic plan (ISU) or low accountability (IJF, ITTF). Specialisation of roles and specialisation due to growing organisational size both contribute to an IFs' levels of commercialisation.

An IF conducting commercial activities through social media states that "the digital communication gives federations the ability to create a value proposition. We have millions of people that like [our sport]. If we can connect them somehow through social media tools, then this [community] becomes a valuable commercial product" (A1). Through interactions with their community, sport organisations can strengthen brand awareness, image and fan loyalty (Coulter, Bruhn, Schoenmueller, \& Schäfer, 2012).

With respect to the third observation, the relatively small degree of overlap of strategic planning and lack of accountability with the outcome of high event commercialisation calls for further investigation. Forster's (2006) contention that commercialisation has increased IFs' governance issues could be linked to the finding that some of the highly commercialised IFs show low accountability (i.e. FINA, WR, IJF, ITTF), but many do not. Meanwhile, recurring external pressures related to scandals may well have given rise to an increased implementation of accountability measures. As FIFA displays a high level of accountability in our findings, doubts may be raised about the accuracy of this conclusion. A report published by Play the Game (2015) attributed a high governance index to FIFA, even though several 
high-ranking FIFA officials had just been arrested for corruption. This example emphasises the difficulty of distinguishing between formally implemented measures of good governance (facade), and truly effective measures (reform). Future research could profitably examine the relation between IFs' commercialisation and their existing/potential governance issues.

The low relevance of strategic planning (only six out of 13 IFs have a strategic plan) is rather surprising. Allison and Kaye (2011) refer to nonprofits' strategic planning as a means to confront business issues such as revenue generation, risk management and cost control, all aspects which IFs face. Talking to a member of the FIH management, this rationale seems to hold true for their case: "How do you future-proof your business? What is the business model going to be in 10, 15 years' time? Marketing and sponsorship are changing. It used to be focussed on television. Now it's moving towards digital. The model will change and you have to be aware of that and adapt" (A3). Analysing planning practices of nonprofit and entrepreneurial organisations, Stone and Brush (1996) provide a possible explanation for the current situation: the dilemma of meeting needs for commitment and demands for legitimacy. The former refers to the need for informal interaction to develop shared perceptions in a context of multiple constituencies and diverging interests. The latter dilemma refers to demands for goal-oriented action and the use of formal systems that accompany acquired legitimacy. Clearly defined goals might prevent certain constituencies from committing themselves to participate in the organisation. The example of FIS, which is in the process of developing a strategic plan, exemplifies this dilemma: "The biggest challenge concerns differences between national federations regarding needs and expectations. Sport, and perhaps the desire for more money, is the only common denominator" $(\mathrm{C} 2)$. At the same time, to satisfy legitimacy demands from resource suppliers, IFs must demonstrate managerial practices such as formalisation and clear goal setting. Caught between the two pressures, many IFs seemingly prefer to keep their goals vague and adaptable to the individual expectations of various constituencies.

A final finding is IFs' apparent business-like behaviour (13 out of 22 IFs analysed demonstrate high event commercialisation). Businesses seek profit maximisation, distribution of profits is based on exchange, goals are specific and clear, and actors' motivation is material; member-serving NPOs seek member benefit maximisation, distribution of profits is based on solidarity, goals are complex and diffuse and actors' motivation is solidaristic (Toepler \& Anheier, 2004)). However, Maier et al. (2014) observe increasing isomorphism between NPOs and businesses through the arrival of new actors who pursue their own goals 
and interests rather than collective goals (Toepler \& Anheier, 2004), competition for scarce resources (Maier et al., 2014) or new strategic management approaches (Tuckman, 1998). A few recent studies (Clausen et al. [forthcoming]; Phelps \& Kent, 2010; Wagner, 2010) have provided research on isomorphism between IFs and businesses.

We argue that IFs' increasing business-like behaviour has several origins, notably the professionalisation and internationalisation of sport, as well as growing commodification and financial uncertainty. The desire and capacity of some IFs to capitalise on commodification has resulted in growing competition. Responses to financial uncertainty due to growing competition can create additional complexity. In turn, growing complexity requires multifaceted managerial approaches including management of (resource) dependencies (Toepler \& Anheier, 2004) and the capacity to interact with those that control resources (Froelich, 1999). Despite growing complexity and the growth of commercial revenues, the mission and goals of IFs' are unchanged (i.e. to regulate, develop, promote and organise their sport). At the same time, IFs' profit redistribution models and the benefits to stakeholders remain opaque or undisclosed.

\section{Implications and limitations}

In terms of commercialisation, this study on 22 Olympic IFs found that a headcount of 30 staff or more presents a critical mass to achieve high event commercialisation. Implications for organisational complexity (e.g. standardisation, formalisation, centralisation) and other related aspects (e.g. strategic capability, leadership) require further research and elaboration. IFs with fewer than 30 staff but with high event commercialisation have witnessed high social media engagement. This suggests that a strong social media presence could help IFs with smaller budgets to grow their sport's community, create brand awareness and attract business partners.

The research indicates that NPOs may face a dilemma in meeting needs for commitment and demands for legitimacy in a context of multiple constituencies. With increasing resources from business partners who seek a return on investment, IFs need to demonstrate goal-orientation to satisfy their business partners. At the same time, IFs are beholden first and foremost to their members (NFs), who may have diverging goals and expectations. Only one-third of the analysed IFs had published a strategic plan, suggesting goal vagueness, at least within the public domain. The phenomenon of goal vagueness leads to a fundamental question: to what extent does IFs' use of market mechanisms serve missionrelated purposes for the largest possible number of members, and to what extent do a few 
actors exploit it to satisfy self-interests? Recurring scandals in some IFs reveal two challenges in this regard: the need for improved governance and possible mission drift or sector bending.

With regard to mission drift, Olympic IFs increasingly have to demonstrate improved control, transparency and accountability mechanisms in order to maintain or regain their legitimacy and autonomy as governing bodies. Both historical and recent governance issues and corruption together with growing commercialisation, all require good governance procedures. To avoid a mission drift, IFs need to consider whether market pressures and business operations and a commercial culture are pulling their organisation "away from their original social mission" (Dees \& Anderson, 2003). Future studies could therefore develop in a more comprehensive understanding of IFs' commercialisation, investigating both negative (e.g. mission drift, increased governance issues) and positive impacts (e.g. increased rationalisation, professionalisation, self-sufficiency).

Limitations to this study include only analysing Olympic IFs for which financial statements were available. To obtain more information from IFs in the future, use could be made of the umbrella organisations ASOIF, AIOWF (Association of International Olympic Winter Sports Federations), ARISF (Association of IOC Recognised International Sport Federations), AIMS (Alliance of Independent Recognised Members of Sport), SportAccord or even the IOC. This could eventually increase pressure on IFs to be more responsive. Future studies could also extend the scope to non-Olympic IFs. This should enable improved comparisons across IFs and would potentially consolidate and extend the findings of this study. The use of differing periods of investigation regarding the outcome and conditions was mentioned earlier, and is a limitation of the research.

The sample size did not allow for an in-depth analysis of IFs' revenues and expenses. A general difficulty here is that many IFs do not provide detailed information. For instance, the IJF spent 41 percent of its 2012-2014 expenses (about $€ 15.2$ million $^{2}$ ) on "travelling expenses". Despite this significant expenditure, there is little detailed information. The csQCA method further masks finer distinctions because of its dichotomous nature. For future studies, the application of a fuzzy-set QCA (fsQCA) represents a possible solution. By using scores on a continuum between 0.0 and 1.0, fsQCA produces more nuanced results. Another constraint related to the QCA method is the static time perspective. Rihoux (2003) notes that the QCA method "is static in its essence. It does not allow one to include the time dimension and hence does not deal with process" (p. 340). As Rihoux and Ragin (2008) emphasise, the QCA method "is a tool to enhance our comparative knowledge about cases in small- and intermediate-N research design" (p. 65). Furthermore, the strategy of using logical remainders 
in conjunction with Boolean minimisation algorithms has raised some criticism (Markoff, 1990; Romme, 1995) as it introduces cases that have not been observed only because they are logically possible. Although our study clearly has some shortcomings, to our knowledge, no study to date has compared IFs' on commercialisation. IFs' commercialisation is an illdefined and often stigmatised concept. By using QCA as an innovative research method to analyse 22 Olympic IFs, this study enhances our comparative knowledge regarding the impact of conditions facilitating high commercialisation. The study further points out the need to investigate both the positive and negative impacts of IFs' commercialisation.

\section{Notes}

1. We first added up the IF's incomes for the years for which financial statements are available, not including Olympic revenue (Sum A). As the 2012-2015 Olympic revenue allocated to the summer Olympic IFs is known to us, we multiplied a quarter of this by the number of years for which the IF's financial statements are available (Sum B). Finally, we added up Sum A and Sum B. As the 2010-2013 Olympic revenue allocated to the Olympic winter IFs is not known to us, we cannot apply normalisation rules in these cases.

2. We converted the currency used in the IJF's financial reports (i.e. Swiss francs) into Euros, based on the exchange rate of 31 July 2014 (CHF $1=$ EUR 0.82195).

\section{References}

Abeza, G., O’Reilly, N., \& Reid, I. (2013). Relationship marketing and social media in sport. International Journal of Sport Communication, 6(2), 120-142.

Allison, M., \& Kaye, J. (2011). Strategic planning for nonprofit organizations: A practical guide and workbook. Hoboken, NJ: John Wiley \& Sons.

Amis, J., Slack, T., \& Hinings, C. R. (2004). Strategic change and the role of interests, power, and organizational capacity. Journal of Sport Management, 18(2), 158-198.

Bayle, E. (2015). The sport federations' perspective. In M. M. Parent \& J.-L. Chappelet (Eds.), The Routledge Handbook of Sports Event Management (pp. 109-122). New York: Routledge.

Bayle, E., \& Rayner, H. (2016). Sociology of a scandal: the emergence of 'FIFAgate'. Soccer \& Society, 1-19. doi:10.1080/14660970.2016.1228591 
Bayle, E., \& Robinson, L. (2007). A framework for understanding the performance of national governing bodies of sport. European Sport Management Quarterly, 7(3), 249268.

Belot, M., Winand, M., \& Kolyperas, D. (2016). How do International Sport Federations Communicate Through Social Media: A content Analysis of FIFA's Twitter Communications. EURAM 2016: Manageable Cooperation? 1.6.-4.6.2016, Paris. Available from: http://2016.euramfullpaper.org/program/search.asp?qs=Dimitrios\%20Kolyperas

Berg-Schlosser, D., De Meur, G., Rihoux, B., \& Ragin, C. (2008). Qualitative comparative analysis (QCA) as an approach. In B. Rihoux \& C. Ragin (Eds.), Configurational comparative methods: qualitative comparative analysis (QCA) and related techniques (pp. 1-18). Thousand Oaks/London: Sage.

Berrett, T., \& Slack, T. (2001). A framework for the analysis of strategic approaches employed by non-profit sport organisations in seeking corporate sponsorship. Sport Management Review, 4(1), 21-45.

Bryson, J. M. (1988). A strategic planning process for public and non-profit organizations. Long Range Planning, 21(1), 73-81.

Carroll, D. A., \& Stater, K. J. (2009). Revenue diversification in nonprofit organizations: Does it lead to financial stability? Journal of Public Administration Research and Theory, 19(4), 947-966.

Chang, C. F., \& Tuckman, H. P. (1994). Revenue diversification among non-profits. Voluntas: International Journal of Voluntary and Nonprofit Organizations, 5(3), 273290.

Chantelat, P. (2001). La professionnalisation des organisations sportives: nouveaux enjeux, nouveaux débats. Paris: L'Harmattan.

Chappelet, J.-L. (2011). Towards better Olympic accountability. Sport in Society, 14(03), 319-331.

Clausen, J., \& Bayle, E. (2017). Major sport events at the centre of international sport federations' resource strategy. In M. Dodds, K. Heisey \& A. Ahonen (Eds.), Routledge Handbook of International Sport Business (pp. 37-53). New York: Routledge.

Clotfelter, C. T., \& Ehrlich, T. (2001). Philanthropy and the nonprofit sector in a changing America. In C. T. Clotfelter \& T. Ehrlich (Eds.), The world we must build (pp. 499516). Bloomington, IN: Indiana University Press. 
Coghlan, A., \& Noakes, S. (2012). Towards an understanding of the drivers of commercialization in the volunteer tourism sector. Tourism Recreation Research, $37(2), 123-131$.

Cornelissen, S. (2010). Football's tsars: proprietorship, corporatism and politics in the 2010 FIFA World Cup. Soccer \& Society, 11(1-2), 131-143.

Coulter, K. S., Bruhn, M., Schoenmueller, V., \& Schäfer, D. B. (2012). Are social media replacing traditional media in terms of brand equity creation? Management Research Review, 35(9), 770-790.

Crompton, J. L. (2004). Conceptualization and alternate operationalizations of the measurement of sponsorship effectiveness in sport. Leisure Studies, 23(3), 267-281.

Cronqvist, L. (2011). Tosmana: Tool for Small-N Analysis [Computer software], Version 1.52. Trier: University of Trier.

Dees, J. G., \& Anderson, B. B. (2003). Sector-bending: Blurring lines between nonprofit and for-profit. Society, 40(4), 16-27.

Dowling, M., Edwards, J., \& Washington, M. (2014). Understanding the concept of professionalisation in sport management research. Sport Management Review, 17(4), 520-529.

Enjolras, B. (2002). The commercialization of voluntary sport organizations in Norway. Nonprofit and Voluntary Sector Quarterly, 31(3), 352-376.

FIFA. (2016). FIFA Forward Football Development Programme. Available from: http://www.fifa.com/development/fifa-forward-programme/index.html

Fiss, P. C. (2007). A set-theoretic approach to organizational configurations. Academy of Management Review, 32(4), 1180-1198.

Fiss, P. C. (2011). Building better causal theories: A fuzzy set approach to typologies in organization research. Academy of Management Journal, 54(2), 393-420.

Forster, J. (2006). Global sports organisations and their governance. Corporate Governance: The International Journal of Business in Society, 6(1), 72-83.

Forster, J, \& Pope, N. (Eds.). (2004). The political economy of global sports organisations. London: Routledge.

Froelich, K. A. (1999). Diversification of revenue strategies: Evolving resource dependence in nonprofit organizations. Nonprofit and Voluntary Sector Quarterly, 28(3), 246-268.

Ganter, A., \& Hecker, A. (2014). Configurational paths to organizational innovation: qualitative comparative analyses of antecedents and contingencies. Journal of Business Research, 67(6), 1285-1292. 
Geeraert, A. (2015). Sports Governance Observer 2015: the legitimacy crisis in international sports governance. Copenhagen: Play the Game.

Girginov, V., \& Sandanski, I. (2008). Understanding the changing nature of sports organisations in transforming societies. Sport Management Review, 11(1), 21-50.

Greckhamer, T., Misangyi, V. F., Elms, H., \& Lacey, R. (2008). Using qualitative comparative analysis in strategic management research: An examination of combinations of industry, corporate, and business-unit effects. Organizational Research Methods, 11(4), 695-726.

Hargreaves, J. (2002). Globalisation theory, global sport, and nations and nationalism. In J. Sugden \& A. Tomlinson (Eds.), Power games: A critical sociology of sport (pp. 2543). London: Routledge.

Houlihan, B. (Ed.). (1997). Sport, policy and politics: A comparative analysis. London: Routledge.

Kikulis, L. M. (2000). Continuity and change in governance and decision making in national sport organizations: Institutional explanations. Journal of Sport Management, 14(4), 293-320.

Krieger, J. (2016). 'The Sole Anti-Democratic Federation in the Entire Olympic Movement': Early International Association of Athletics Federations Development Initiatives Between Commercialization and Democratization, 1974-1987. The International Journal of the History of Sport, 33(12), 1341-1360.

Legewie, N. (2013). An introduction to applied data analysis with qualitative comparative analysis. Forum Qualitative Sozialforschung/Forum: Qualitative Social research, 14(3), 1-9. Available from: http://nbn.resolving.de/urn:nbn:de:0114-fqs1303154.

Li, M., MacIntosh, E., \& Bravo, G. (Eds.). (2012). International sport management. Champaign, IL: Human Kinetics.

MacAloon, J. J. (2011). Scandal and governance: inside and outside the IOC 2000 Commission. Sport in Society, 14(03), 292-308.

Macedo, I. M., \& Carlos Pinho, J. (2006). The relationship between resource dependence and market orientation: The specific case of non-profit organisations. European Journal of Marketing, 40(5/6), 533-553.

Maggetti, M., \& Levi-Faur, D. (2013). Dealing with errors in QCA. Political Research Quarterly, 66(1), 198-204. 
Maier, F., Meyer, M., \& Steinbereithner, M. (2014). Nonprofit Organizations Becoming Business-Like A Systematic Review. Nonprofit and Voluntary Sector Quarterly, 45(1), 64-86.

Markoff, J. (1990). A Comparative Method: Reflections on Charles Ragin's Innovations in Comparative Analysis. Historical Methods: A Journal of Quantitative and Interdisciplinary History, 23(4), 177-181.

Marx, A., Rihoux, B., \& Ragin, C. (2014). The origins, development, and application of Qualitative Comparative Analysis: the first 25 years. European Political Science Review, 6(01), 115-142.

Nagel, S., Schlesinger, T., Bayle, E., \& Giauque, D. (2015). Professionalisation of sport federations-a multi-level framework for analysing forms, causes and consequences. European Sport Management Quarterly, 15(4), 407-433.

O'Brien, D., \& Slack, T. (2004). The emergence of a professional logic in English rugby union: The role of isomorphic and diffusion processes. Journal of Sport Management, 18(1), 13-39.

Parent, M. M., \& Séguin, B. (2007). Factors that led to the drowning of a world championship organizing committee: A stakeholder approach. European Sport Management Quarterly, 7(2), 187-212.

Pielke, R. (2013). How can FIFA be held accountable? Sport Management Review, 16(3), 255-267.

Pinson, J. (2017). Heritage sporting events: theoretical development and configurations. Journal of Sport \& Tourism, 21(2), 133-152.

Ragin, C. (Ed.). (1987). The comparative method: Moving beyond qualitative and quantitative methods. Berkeley: University of California.

Ragin, C. (2006). Set relations in social research: Evaluating their consistency and coverage. Political Analysis, 14(3), 291-310.

Ragin, C. (Ed.). (2008). Redesigning social inquiry: Fuzzy sets and beyond. Chicago: University of Chicago Press.

Ragin, C., \& Davey, S. (2009). fs/QCA [Computer Programme], Version [2.5/3.0]. Irvine, CA: University of California.

Ragin, C., \& Rihoux, B. (2004). Qualitative comparative analysis (QCA): State of the art and prospects. Qualitative Methods, 2(2), 3-13.

Ratten, V. (2016). Sport innovation management: towards a research agenda. Innovation, 113. doi: $10.1080 / 14479338.2016 .1244471$ 
REDTORCH. (2017). Sport on Social 2017. Retrieved May 13, 2017, from http://www.redtorch.co/download-sport-on-social-2017

Rihoux, B. (2003). Bridging the gap between the qualitative and quantitative worlds? A retrospective and prospective view on qualitative comparative analysis. Field Methods, 15(4), 351-365.

Rihoux, B. (2006). Qualitative comparative analysis (QCA) and related systematic comparative methods: Recent advances and remaining challenges for social science research. International Sociology, 21(5), 679-706.

Rihoux, B., \& De Meur, G. (2009). Crisp-set Qualitative Comparative Analysis (csQCA). In B. Rihoux \& C. Ragin (Eds.), Configurational comparative methods: qualitative comparative analysis (QCA) and related techniques (pp. 33-67). Thousand Oaks, CA: Sage.

Rihoux, B, \& Ragin, C. (Eds.). (2008). Configurational comparative methods: Qualitative comparative analysis (QCA) and related techniques. London: Sage.

Robinson, L. (2003). The business of sport. In B. Houlihan (Ed.), Sport \& society: a student introduction (pp. 165-183). London: Sage Publications.

Romme, A. G. L. (1995). Boolean comparative analysis of qualitative data. Quality and Quantity, 29(3), 317-329.

Schneider, C. Q., \& Wagemann, C. (2010). Standards of good practice in qualitative comparative analysis (QCA) and fuzzy-sets. Comparative Sociology, 9(3), 397-418.

Schneider, M. R., Schulze-Bentrop, C., \& Paunescu, M. (2010). Mapping the institutional capital of high-tech firms: A fuzzy-set analysis of capitalist variety and export performance. Journal of International Business Studies, 41(2), 246-266.

Skinner, J., Stewart, B., \& Edwards, A. (1999). Amateurism to professionalism: Modelling organisational change in sporting organisations. Sport Management Review, 2(2), 173 192.

Slack, T. (Ed.). (2004). The commercialisation of sport. New York: Routledge.

Slack, T. (2014). The social and commercial impact of sport, the role of sport management. European Sport Management Quarterly, 14(5), 454-463.

Smith, A., \& Stewart, B.. (2010). The special features of sport: A critical revisit. Sport Management Review, 13(1), 1-13.

Smith, S. R. (2010). Hybridization and nonprofit organizations: The governance challenge. Policy and Society, 29(3), 219-229. 
Smith, S. R. (2016). Cross-sector Nonprofit-Government Financing. In E. T. Boris \& C. E. Steuerle (Eds.), Nonprofits and Government: Collaboration and Conflict (pp. 103132). Lanham: Rowman \& Littlefield.

Stone, M. M., \& Brush, C. G. (1996). Planning in ambiguous contexts: The dilemma of meeting needs for commitment and demands for legitimacy. Strategic Management Journal, 17(8), 633-652.

Thibault, L., Kihl, L., \& Babiak, K. (2010). Democratization and governance in international sport: addressing issues with athlete involvement in organizational policy. International Journal of Sport Policy, 2(3), 275-302.

Thibault, L., Slack, T., \& Hinings, B. (1991). Professionalism, structures and systems: The impact of professional staff on voluntary sport organizations. International Review for the Sociology of Sport, 26(2), 83-98.

Thiem, A., \& Dusa, A. (2013). QCA: A package for qualitative comparative analysis. The $R$ Journal, 5(1), 87-97.

Thomann, E. (2015). Is output performance all about the resources? A fuzzy- set qualitative comparative analysis of street- level bureaucrats in Switzerland. Public administration, 93(1), 177-194.

Toepler, S. (2004). Conceptualizing nonprofit commercialism: A case study. Public Administration and Management: an Interactive Journal, 9(4), 1-19.

Toepler, S., \& Anheier, H. K. (2004). Organizational theory and nonprofit management: an overview. In A. Zimmer \& E. Priller (Eds.), Future of Civil Society (pp. 253-270). Wiesbaden: VS Verlag.

Tomlinson, A. (2005). The commercialization of the Olympics: Cities, corporations and the Olympic commodity. In K. Young \& K. Wamsley (Eds.), Global Olympics: Historical and Sociological Studies of the Modern Games (pp. 179-200). Oxford: Elsevier.

Tuckman, H. P. (1998). Competition, commercialization, and the evolution of nonprofit organizational structures. Journal of Policy Analysis and Management, 17(2), 175194.

Wagner, U. (2010). The International Cycling Union under Siege-Anti-doping and the Biological Passport as a Mission Impossible? European Sport Management Quarterly, $10(3), 321-342$.

Weisbrod, B. A. (Ed.). (1998). To profit or not to profit: The commercial transformation of the nonprofit sector. Cambridge, MA: Cambridge University Press. 
Wemmer, F., \& Koenigstorfer, J. (2016). Open innovation in nonprofit sports clubs. Voluntas: International Journal of Voluntary and Nonprofit Organizations, 27(4), 1923-1949.

Wicker, P., Feiler, S., \& Breuer, C. (2013). Organizational mission and revenue diversification among non-profit sports clubs. International Journal of Financial Studies, 1(4), 119-136.

Winand, M., Rihoux, B., Qualizza, D., \& Zintz, T. (2011). Combinations of key determinants of performance in sport governing bodies. Sport, Business and Management: An International Journal, 1(3), 234-251.

Winand, M., Rihoux, B., Robinson, L., \& Zintz, T. (2013). Pathways to high performance: A qualitative comparative analysis of sport governing bodies. Nonprofit and Voluntary Sector Quarterly, 42(4), 739-762.

Winand, M., \& Zintz, T. (2013). Qualitative comparative analysis of sport governing bodies: a tool on ways towards high performance. In S. Söderman \& H. Dolles (Eds.), Handbook of research on sport and business (pp. 76-93). Cheltenham, UK: Edward Elgar.

Winand, M., Qualizza, D., Vos, S., Scheerder, J., \& Zintz, T. (2013). Fédérations sportives innovantes: attitude, perceptions et champions de l'innovation [Innovative sport federations: attitude, perceptions and innovation champions]. Revue Interdisciplinaire sur le Management et l'Humanisme, 6, 6-21.

Young, D. R. (1998). Commercialism in nonprofit social service associations: Its character, significance, and rationale. Journal of Policy Analysis and Management, 278-297. 
Table 1. Initial list of conditions for IFs' commercialisation

\begin{tabular}{|c|c|c|c|}
\hline Conditions & Source & Indicators & Applicability \\
\hline $\begin{array}{l}\text { Financial independence } \\
\text { from the Olympic revenue } \\
\text { share (ORS) }\end{array}$ & Interview (ASOIF) & $\begin{array}{l}\text { Part of the ORS in the overall } \\
\text { revenue (average dependence } \\
\text { of summer Olympic IFs on } \\
\text { the ORS according to } \\
\text { ASOIF: about } 40 \% \text { ) }\end{array}$ & $\begin{array}{l}\text { No. Findings of a first analysis showed that the } \\
\text { condition was sufficient to achieve high } \\
\text { commercialisation. As in the case of decreasing } \\
\text { private donations and public funding in general NPO } \\
\text { literature, we believe this view is too simplistic. }\end{array}$ \\
\hline Social/digital media & $\begin{array}{l}\text { Literature (Abeza, et al., } \\
\text { 2013; Belot et al., 2016) + } \\
\text { IOC Evaluation Criteria + } \\
\text { interview (e.g. UWW) }\end{array}$ & $\begin{array}{l}\text { Social media engagement } \\
\text { (i.e. Facebook, Twitter, } \\
\text { Instagram) }\end{array}$ & Yes \\
\hline Media coverage & IOC Evaluation Criteria & $\begin{array}{l}\mathrm{N}^{\circ} \text { of media accreditations at } \\
\text { the World Championships }\end{array}$ & No. Numbers are only available for 2012 and before. \\
\hline Specialisation & $\begin{array}{l}\text { Literature (Bayle \& } \\
\text { Robinson, 2007) }\end{array}$ & $\begin{array}{l}\text { Headcount, departments, } \\
\text { hierarchical levels }\end{array}$ & Yes \\
\hline Strategy/goal orientation & $\begin{array}{l}\text { Literature (Stone \& Brush, } \\
\text { 1996) + IOC Evaluation } \\
\text { Criteria + interviews (e.g. } \\
\text { FIH, FIS) }\end{array}$ & Strategic plan & Yes \\
\hline Popularity of the sport & Interviews (e.g. FIH, FISA) & $\mathrm{N}^{\circ}$ of licence holders & $\begin{array}{l}\text { No. Most IFs do not know the number of licence } \\
\text { holders as these are registered with their NFs. }\end{array}$ \\
\hline Capacity of innovation & $\begin{array}{l}\text { Literature (e.g. Ratten, 2016; } \\
\text { Wemmer \& Koenigstorfer, } \\
\text { 2016; Winand et al., 2013) }\end{array}$ & $\begin{array}{l}\text { Introduction of new activities } \\
\text { and services and their } \\
\text { benefits }\end{array}$ & $\begin{array}{l}\text { No. Very time-intensive research. The general lack } \\
\text { of research on this topic requires a study of its own. }\end{array}$ \\
\hline Revenue diversification & $\begin{array}{l}\text { Literature (Carroll \& Stater, } \\
\text { 2009) }\end{array}$ & $\begin{array}{l}\mathrm{N}^{\circ} \text { of cash sponsors and their } \\
\text { part in the overall revenue }\end{array}$ & No. Information is not available. \\
\hline
\end{tabular}


Table 2. Raw data table (35 IFs)

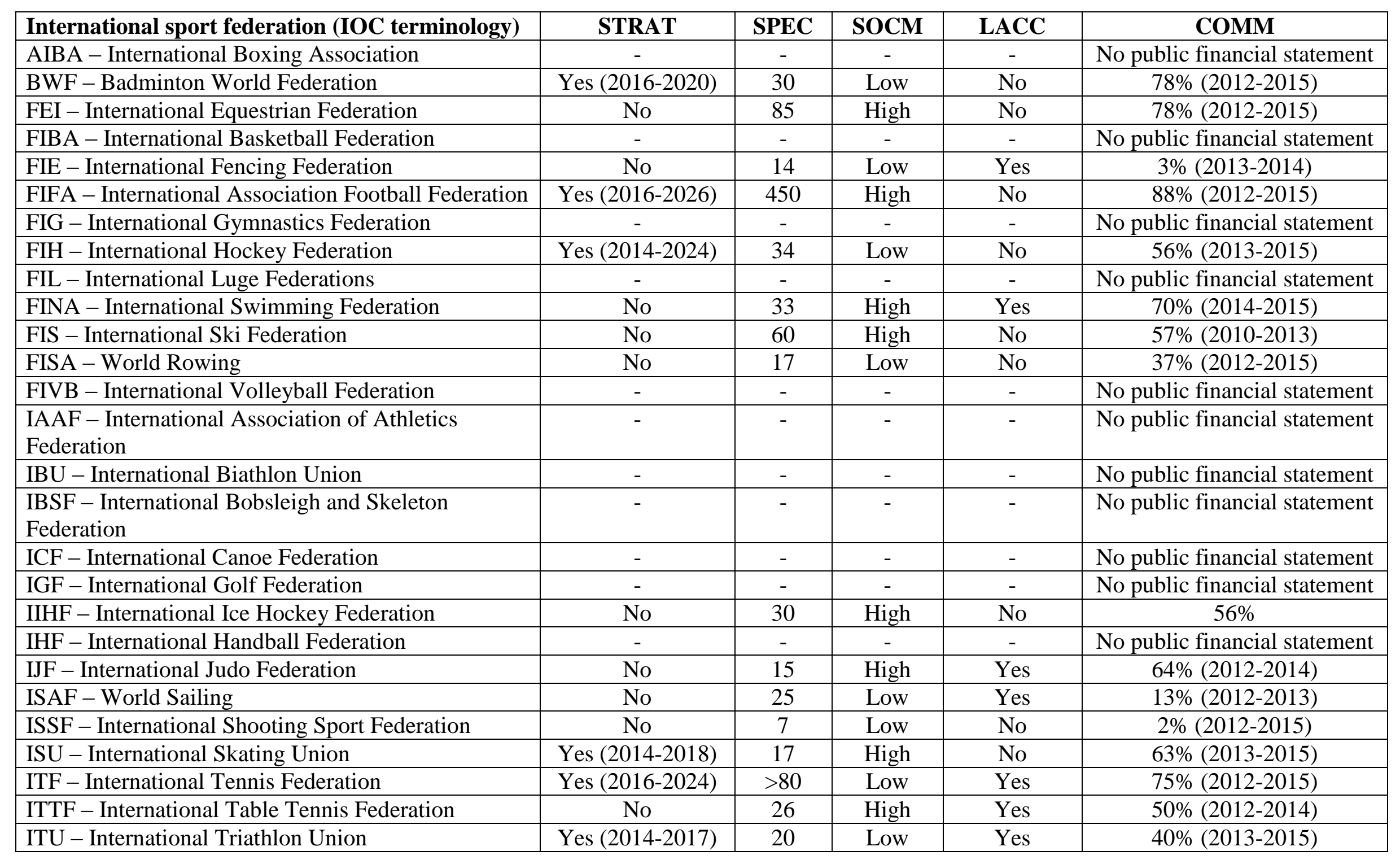




\begin{tabular}{|l|c|c|c|c|c|}
\hline IWF - International Weightlifting Federation & No & $13-19$ & Low & Yes & $17 \%(2013-2014)$ \\
\hline UCI - International Cycling Union & No & 79 & High & No & $70 \%(2012-2015)$ \\
\hline UIPM - International Modern Pentathlon Union & - & - & - & - & No public financial statement \\
\hline UWW - United World Wrestling & No & 24 & High & No & $29 \%(2014-2015)$ \\
\hline WA - World Archery Federation & No & 14 & High & No & $31 \%(2012-2014)$ \\
\hline WCF - World Curling Federation & Yes (2015-2018) & 12 & Low & No & $20 \%(2012-2015)$ \\
\hline WR - World Rugby & Yes (2010-2020) & 75 & High & Yes & $97 \%(2012-2015)$ \\
\hline WTF - World Taekwondo Federation & - & - & - & - & No public financial statement \\
\hline
\end{tabular}

Note: STRAT, strategic planning; SPEC, specialisation; SOCM, social media engagement; LACC, low accountability; COMM, commercialisation 
Table 3. Truth table without contradictions

\begin{tabular}{lcccc|c}
\hline FEDERATION & STRAT & SPEC & SOCM & LACC & COMM \\
\hline FISA, ISSF & 0 & 0 & 0 & 0 & 0 \\
WCF & 1 & 0 & 0 & 0 & 0 \\
FIE, ISAF, IWF & 0 & 0 & 0 & 1 & 0 \\
UWW, WA & 0 & 0 & 1 & 0 & 0 \\
ITU & 1 & 0 & 0 & 1 & 0 \\
BWF, FIH, ITF & 1 & 1 & 0 & 0 & 1 \\
ISU & 1 & 0 & 1 & 0 & 1 \\
IJF, ITTF & 0 & 0 & 1 & 1 & 1 \\
FEI, FIS, IIHF, UCI & 0 & 1 & 1 & 0 & 1 \\
FIFA & 1 & 1 & 1 & 0 & 1 \\
FINA & 0 & 1 & 1 & 1 & 1 \\
WR & 1 & 1 & 1 & 1 & 1
\end{tabular}

Note: STRAT, strategic planning; SPEC, specialisation; SOCM, social media engagement;

LACC, low accountability; COMM, commercialisation

Table 4. Necessity analysis

\begin{tabular}{|l|l|l|l|l|}
\hline & \multicolumn{3}{|l}{ COMM } & $\sim$ COMM \\
\hline & Consistency & Coverage & Consistency & Coverage \\
\hline STRAT & 0.461538 & 0.750000 & 0.22 & 0.25 \\
\hline$\sim$ STRAT & 0.538462 & 0.500000 & 0.78 & 0.50 \\
\hline SPEC & 0.769231 & 1.000000 & 0.00 & 0.00 \\
\hline$\sim$ SPEC & 0.230769 & 0.250000 & 1.00 & 0.75 \\
\hline SOCM & 0.769231 & 0.833333 & 0.22 & 0.17 \\
\hline$\sim$ SOCM & 0.230769 & 0.300000 & 0.78 & 0.70 \\
\hline LACC & 0.307692 & 0.500000 & 0.44 & 0.50 \\
\hline$\sim$ LACC & 0.692308 & 0.642857 & 0.56 & 0.36 \\
\hline
\end{tabular}


Table 5. Analysis of intermediate solutions

\begin{tabular}{|c|c|c|c|c|}
\hline \multicolumn{5}{|c|}{ High commercialisation (COMM) } \\
\hline & $S P E C+$ & $S O C M^{*} L A C C+$ & $S O C M * S T R A T$ & $\rightarrow C O M M$ \\
\hline $\begin{array}{l}\text { Single case } \\
\text { coverage }\end{array}$ & $\begin{array}{l}\text { BWF, FIH, ITF, FEI, } \\
\text { FIFA, FIS, IIHF, UCI, } \\
\text { FINA, WR }\end{array}$ & $\begin{array}{l}\text { FINA, IJF, } \\
\text { ITTF, WR }\end{array}$ & ISU, FIFA, WR & \\
\hline Consistency & 1 & 1 & 1 & \\
\hline $\begin{array}{l}\text { Raw } \\
\text { coverage }\end{array}$ & 0.769 & 0.308 & 0.231 & \\
\hline $\begin{array}{l}\text { Unique } \\
\text { coverage }\end{array}$ & 0.538 & 0.154 & 0.077 & \\
\hline & & \multicolumn{2}{|c|}{ Solution consistency: } & 1 \\
\hline & & \multicolumn{2}{|c|}{ Solution coverage: } & 1 \\
\hline \multicolumn{5}{|c|}{ Low commercialisation ( COMM) } \\
\hline & $\sim S P E C^{*} \sim S O C M+$ & \multicolumn{2}{|c|}{$\sim S T R A T^{*} \sim S P E C^{*} \sim L A C C$} & $\rightarrow \sim C O M M$ \\
\hline $\begin{array}{l}\text { Single case } \\
\text { coverage }\end{array}$ & $\begin{array}{l}\text { FIE, ISAF, IWF, FISA, } \\
\text { ISSF, ITU, WCF }\end{array}$ & \multicolumn{2}{|c|}{ FISA, ISSF, UWW, WA } & \\
\hline Consistency & 1 & \multicolumn{2}{|l|}{1} & \\
\hline $\begin{array}{l}\text { Raw } \\
\text { coverage }\end{array}$ & 0.778 & \multicolumn{2}{|l|}{0.444} & \\
\hline $\begin{array}{l}\text { Unique } \\
\text { coverage }\end{array}$ & 0.556 & \multicolumn{2}{|l|}{0.222} & \\
\hline & & \multicolumn{2}{|c|}{ Solution consistency: } & 1 \\
\hline & & \multicolumn{2}{|c|}{ Solution coverage: } & 1 \\
\hline
\end{tabular}

